\title{
Sexual Education for Wholesome Sexual Behaviour among in-School Nigerian Adolescents
}

\author{
Oyenike Alake Oyinloye \\ Department of Educational Foundations and Counselling \\ Adeyemi College of Education, Ondo, Nigeria
}

\begin{abstract}
The study investigated the influence of sexual education in the enhancement of wholesome sexual behaviours among adolescent students in Nigeria. Three hundred students and sixty teachers were drawn from ten (10) schools in urban and rural areas of Ondo state, using a self constructed rating scale to collect data from them. The data were collated and analysed using t-test and percentage statistical analysis to test the two hypotheses generated for the study. The results of the findings revealed that there was significant influence of sex education on secondary school students sexual behaviours and that a significant majority of the students are curious to get information about their sexual life. A significant majority of students in the urban setting have higher level of awareness on sexual activities than their rural counterparts. Majority of the students agreed that sex education will assist them to develop a wholesome sexual behaviour. Based on the findings, it was recommended that concentrated efforts should be made by the government, parents and the school. A complementary effort of the school and the home in the provision of information and services to help the adolescents in the understanding of their sexuality and to protect them from unwholesome sexual attitude, sexually transmitted diseases and subsequent risk of infertility, unwanted pregnancy and possible problem of HIV and AIDS.
\end{abstract}

\section{Introduction}

Sex education has attracted great attention among Nigerian populace in recent times. Parents, teachers and concerned adults are becoming more disturbed by the increasing incidence of teenage pregnancy and consequent drop out of school by pregnant teenagers, incidence of sexually transmitted diseases and cases of HIV and AIDS infection among the young school age children. Other sexual problems among adolescence include cases of forcible sexual behaviour and sexual harassment.

In Nigeria, and other African cultures the subject of sex is considered sacred and not intended to be loosely discussed especially by the young ones. Oyinloye observes that when a child carelessly talk about sex, the parents could reprimand the child for talking about a subject considered sacred [12]. Olorunda alerts that lack of information on issues related to sex has made many of the young ones to be unprotected in their sexual exploration while this has endangered the life and future of many of them [11].

The period of adolescence is a unique stage in the life of every person. Adegoke describes the stage as a stage when lots of physiological as well as anatomical changes take place resulting in reproductive maturity in adolescents [2]. Sandtrock also observed that during adolescence, the lives of males and females become wrapped in sexuality. To him, the adolescence is a time of sexual exploration hence incorporating sexuality is a normal aspect of human development and as such should not be presented as scary and sinful for adolescent to have a view and understanding about sexuality [13].

Kirby observes that many adolescents manage the transformation in adolescence successful while others experience major stress and find themselves engaging in negative sexual behaviours such as sexual experimentation, exploration and promiscuity that place them at risk [6].

Kirby opines that the phenomenon of teenage girls getting pregnant is a contemporary social issue in some nations especially in Nigeria where it has now become a common occurrence [7]. A number of reasons may be adduced for incidence of teenage pregnancy. Okafor and Nnoli identify lack of affectionate supervision of parents and guardians as a factor in adolescence or teenage pregnancy. They also observed that about 13 million children are born from teenage girls living in underdeveloped 
countries and that USA also top the list in pregnancy and teenage abortion across the world [9].

A number of factors were identified as causes of teenage pregnancy and lack of sex education tops the list presented by Okafor and Nnoli [9]. With this astonishing revelation, it is expected that the young ones should be given enlightenments on sexual matters and parents should provide sex education for their children right from home. It is believed that with information on sex education, the adolescents would be better prepared against unguarded sexual exploration and its consequential hazards.

Against this background, it is clear that the problem of unwholesome sexual exploration among adolescents is as a result of the extent of lack of sexual information. Esere alerts that the consequence of lack of information on sex related issues and questions make Nigerian adolescent boys and girls to find answers to sex related questions on their own, and often they receive answers from questionable sources that are likely to give them wrong information and make them indulge in reckless and unguarded sexual experimentation [5]. Abogunrin states that lack of adequate communication and assertive skills to negotiate safer sex among adolescents make many of them unable to refuse unwanted sex or feel compelled to exchange sex for money [1]. Many young people also experiment sexual activities, many fall victim of physical consequences such as premature loss of virginity, unwanted pregnancy, illegitimate child, forced marriage, abortion and sexually transmitted diseases. Beyond the tragic physical effects, some devastating psychological and relational problems that follow premarital sex include emotional distress, self hatred, sexual addiction and spiritual bondage result.

Adepoju is of the opinion that sexuality education acquaint the youth with factual and accurate sexual information about the dimension of sexual knowledge that will enable them understand and clarify their personal values and improve their knowledge which will in turn assist them in sexual decision making [4]. Obiekea, Ovri and Chulwuma are also of strong believe that sexual education enables the adolescents to be well guarded and better able to face challenges related to sex and sexuality [8].

The need to mount sex education programmes geared, towards enlightenment and appropriate education about sex and sexuality now forms the main thrust of this study. The study was therefore carried out to examine the importance of sex education and the effect of sexual education with the view of pointing out the effect it could have on the sexual behaviour of adolescent students in Secondary Schools in the study area.

\section{Aim and objective of the Study}

This study is designed to assess how sexual education can bring about a wholesome sexual attitude among Nigerian adolescent with a view to suggesting measures for inculcating right sexual behaviour. The specific objectives of the study are to:

i. Determine the importance sexual education and how it can influence the sexual behaviour of in- school adolescents in Nigeria.

ii. Examine the level/extent to which sexual education has brought about wholesome sexual behaviour among Nigerian adolescents.

iii. Ascertain the consequence of sexual education on adolescents' sexual behaviour.

\section{Hypotheses}

In order to achieve the stated objectives, the following hypotheses were carried out.

1. There is no significant influence of sex education on secondary school students' sexual behaviour.

2. There is no significant influence of sexual education on rural and urban adolescents.

\section{Research Methodology}

The study adopted a descriptive survey in which the researcher adopted a simple random sampling to select 300 male and female students drawn from ten (10) secondary schools in Ondo State, Nigeria. A structured questionnaire for students, titled Problems and Prospects of Teaching Sex Education (PPTSE) in secondary schools was designed by the researcher was used to elicit information on the need for sexual education and effect on sexual behaviour of students. The responses drawn were scored ranging from Strongly Agree $=4$, Agree $=3$, Disagree $=2$ and Strongly Agree $=1$. The instrument was administered to the students by the researcher after she has encouraged them to complete the instrument individually. The validity was ensured using expert's judgement and the reliability was also ascertained using split-half method to analyse the data collected. Pearson product moment correlation method was used to analyse and the coefficient obtained was 0.87 , which was deemed high enough to be used for the study.

The data collected was analysed using mean, standard deviation and t-test. 


\section{Results}

Two hypotheses were tested using t-test as indicated on the tables below:

Hypothesis 1: There is no significant influence of sex education on secondary school students' sexual behaviour?

Table 1: t-test analysis on the influence of sex education on adolescents' sexual behaviour

\begin{tabular}{|l|c|c|c|c|c|c|c|}
\hline \multicolumn{1}{|c|}{ Variables } & N & X & SD & DF & $\begin{array}{c}\text { T- } \\
\text { Cal }\end{array}$ & $\begin{array}{c}\text { T- } \\
\text { table }\end{array}$ & Decision \\
\hline $\begin{array}{l}\text { Positive view } \\
\text { on sex } \\
\text { education }\end{array}$ & 58.235 .15 & 298 & 7.68 & 1.96 & Reject \\
\hline $\begin{array}{l}\text { Curiosity to get112 } \\
\text { information on } \\
\text { sexual life }\end{array}$ & 52.716 .45 & & & & \\
\hline
\end{tabular}

Table 1 show that the calculated t-value (7.68) was greater than the t-table value (1.96) at 0.05 level of significance. This indicates that there was significant influence of sex education on secondary school students' sexual behaviour. The findings revealed that majority of the students are curious to get information about their sexual life and that sex education should be taught in secondary schools. The null hypothesis was therefore rejected.

Hypothesis 2: There is no significant influence of sexual education on urban and rural adolescents.

Table 2: t-test comparison or urban and rural teenagers' attitude to sexual activities

\begin{tabular}{|l|c|c|c|c|c|c|c|}
\hline Variables & $\mathbf{N}$ & $\mathbf{X}$ & SD & $\mathbf{D . F}$ & $\begin{array}{c}\text { T- } \\
\text { Calcu } \\
\text { lated }\end{array}$ & $\begin{array}{c}\text { T- } \\
\text { table }\end{array}$ & Decision \\
\hline Urban & 160 & 40.73 & 5.57 & 298 & 0.926 & 0.355 & Reject \\
\hline Rural & 140 & 40.48 & 5.40 & - & - & - & - \\
\hline
\end{tabular}

From table 2, it could be seen that the calculated t-value (0.926) was greater than the t-table value $(0.355)$ at 0.05 level of significance. This indicates that there was greater awareness of sexual activities among teenagers in urban areas as against those in rural setting. The differences in the attitude of urban and rural teenagers towards sexual activities could have been environmental factors. The null hypothesis as therefore rejected as there was significant influence of setting on sexual activities.
Table 3: Consequences of sexual education on adolescents

\begin{tabular}{|c|c|c|c|c|}
\hline Items & Agree & $\%$ & Disagree & $\%$ \\
\hline $\begin{array}{l}\text { Early sexual activities } \\
\text { have negative effect on } \\
\text { young people. }\end{array}$ & 270 & 90.0 & 30 & 10.0 \\
\hline $\begin{array}{l}\text { Sex Education should be } \\
\text { taught in schools }\end{array}$ & 300 & 100 & 0 & 0.0 \\
\hline $\begin{array}{lrr}\text { Early sexual } & \text { activity } \\
\text { causes } & \text { secondary } \\
\text { infertility } & \text { and } \\
\text { development of } & \text { cervical } \\
\text { abnormalities } & \text { in } \\
\text { adolescents. } & & \\
\end{array}$ & 267 & 89.0 & 33 & 11.0 \\
\hline $\begin{array}{llr}\text { Secondary } & \text { school } \\
\text { teachers cannot } & \text { handle } \\
\text { sex education } & \text { class } \\
\text { effectively. } & \end{array}$ & 40 & 13.3 & 260 & 86.7 \\
\hline $\begin{array}{l}\text { Sex education } \\
\text { secondary } \\
\text { enhance }\end{array}$ & 20 & 6.7 & 280 & 93.3 \\
\hline $\begin{array}{l}\text { Adolescents are curious } \\
\text { to get information about } \\
\text { their sexual life. }\end{array}$ & 284 & 94.7 & 16 & 5.3 \\
\hline $\begin{array}{l}\text { Sexual education will } \\
\text { prevent young people } \\
\text { from being victim of } \\
\text { sexual harassment, rape, } \\
\text { promiscuity teenage } \\
\text { pregnancy and sexually } \\
\text { transmitted diseases. }\end{array}$ & 289 & 96.3 & 11 & 3.7 \\
\hline $\begin{array}{l}\text { Sex education in } \\
\text { secondary schools will } \\
\text { reduce rate of abortion } \\
\text { mortality. }\end{array}$ & 277 & 92.3 & 23 & 7.7 \\
\hline $\begin{array}{l}\text { Sex education class } \\
\text { should be organised for } \\
\text { both male and female } \\
\text { students. }\end{array}$ & 300 & 100.0 & 0 & 0.0 \\
\hline $\begin{array}{l}\text { Sex education will reduce } \\
\text { rate of unwanted } \\
\text { children. }\end{array}$ & 300 & 100.0 & 0 & 0.0 \\
\hline $\begin{array}{lrr}\text { Sex } & \text { Education } & \text { will } \\
\text { enhance } & \text { positive } & \text { sexual } \\
\text { attitude } & & \\
\end{array}$ & 294 & 98.0 & 06 & 2.0 \\
\hline $\begin{array}{l}\text { Sex Education will help } \\
\text { adolescents to be aware } \\
\text { of problem relating to } \\
\text { abortion }\end{array}$ & 289 & 96.3 & 11 & 3.7 \\
\hline $\begin{array}{lr}\text { Sex Education leads to } \\
\text { wholesome } \\
\text { behaviour }\end{array}$ & 300 & 100 & 0 & 0.0 \\
\hline
\end{tabular}


As indicated in table 3, $300(100 \%)$ of the students agreed that early sexual activities have negative effect on young people. 300(100\%) agreed that sex education should be taught in secondary schools. $260(86.7 \%)$ of the students disagreed with the fact that secondary school teachers cannot handle sex education class effectively. While $300(100 \%)$ of them also agreed that sex education class should be organised for both male and female students. 277 $(92.3 \%)$ agreed that teaching of sex education in secondary schools will reduce the rate of abortion mortality, divorce rate, poverty and unwanted children in the society. On the whole, a greater percentage of the students believe that sexual education will assist students to imbibe a wholesome sexual behaviour.

\section{Discussion of Findings}

The results of the findings revealed that there was significant influence of sex education on secondary school students behaviours and that a significant majority of the students are curious to get information about their sexual life. A significant majority of the students agreed that early sexual activities have negative effect on young people. Oke is of the view that sex education is necessary to prepare the young ones for the task ahead of them. According to him, some kind of planned sex education is necessary [10].

These findings also revealed that there was significant influence of learning on sex education at an early age as to when teenagers become involved in sexual activities. A significant majority of students disagreed with the fact that teaching about sex education in secondary schools will enhance sexual harassment, rape, teenage pregnancy and promiscuity among secondary school students. International evidence suggests that certain aspect of sex and relationship education taught before puberty has a positive effect on issues such as teenage pregnancy [15].

The findings also revealed that a significant majority of the students agreed that sex education class should be organised for both male and female students without any discrepancy. Based on these findings, it is clearly stated through the analysis, that the consequences of early sexual activities on adolescents cause secondary infertility and development of cervical abnormalities in adolescents and that lack of sex education cause many adolescents to be sexually harassed, indulge in rape activity, become promiscuous, victim of unwanted pregnancy and sexually transmitted diseases which place their well-being at risk of HIV/AIDS that leads to physical and emotional damage. Adolescents display sexual behaviours and developmental characteristics that place them at risk for Sexually Transmitted Diseases (STDs), risk of HIV/AIDS and other problems resulting from unprotected and indiscriminate sexual activities. By the time they are 18 years old, most adolescents in Nigeria are sexually active [6].

A study on early sexual intercourse shows that childhood sexual intercourse is associated with several potentially serious indicators of distress and health-compromising behaviours among the young, such as lower academic performance, gang involvement, unprotected and more frequent sexual intercourse, pregnancy, emotional distress, and suicidal involvement [14]. The findings also affirmed that majority of the respondents agreed that sex education should be taught in schools and that their parents should join hands with school to teach sex education. Teachings on sexuality should be taught from early age to enable adolescents to know what can result from undue sexual exploration [3].

\section{Conclusion}

The findings of the study have led the researcher to conclude that sex education is a must to fortify the adolescents with adequate information on sex and sexuality. This is more urgent because young ones are daily bombarded by information on sex and sexuality from various avenues and it is evident that formal teaching on sex and sexuality will simply assist to enlighten them to acquire wholesome attitude and bring about social adjustment needed to fortify them against wrong attitude.

\section{Recommendations}

In order to effectively cater for adolescents' need of sex education, the following recommendations are considered beneficial:

- Sex education should be incorporated into the school curriculum at the secondary level to keep the adolescents informed on sex related issues.

- Sex education if carefully taught from early stage, will enable the young ones to have comprehensive knowledge about their sexuality. This will promote healthy disposition to sexual issues.

- Sexual education will assist the adolescents to recognise healthy and unhealthy sexual exploration. This will better guide their sexual behaviour. 
- Counselling should be organised in all secondary schools to provide necessary information on sex and sexuality.

- Parents and guardians should monitor the activities of the teenagers, they should also provide guidance on sex and sexuality

- Religious groups should also endeavour to give information on sex to the young ones. If they are well informed, there is the likelihood that incidence of unhealthy sexual exploration and teenage pregnancy would be reduced.

\section{References}

[1] Abogunrin, A.J., "Sexual behaviour" Condom use and attitude towards HIV/AIDS among adolescents in Nigeria. An Unpublished Ph.D. thesis, University of Ilorin, (2003).

[2] Adegoke, A.A. "Adolescents in Africa" Revealing the problems of teenagers in contemporary African society, Hadassah Publishing. Ibadan, (2003).

[3] Adenegan, T.S and Ogunlade, O.O. "Teenage Pregnancy among In-School Female Adolescents", Implications for Counselling. Nigeria's Socio-Economic and political Dilemmas: The challenges and way out. Proceedings of $1^{\text {st }}$ Achievers National Conference on Public Policy, (2013), 115-125.

[4] Adepoju, A., "Sexuality Education in Nigeria", Evolution, Challenges and prospects. Retrieved January, 2012 from Google.com, (2005).

[5] Esere, M.O. "HIV/AIDS awareness of in - school adolescents in Nigeria, Implications for adolescents' sexuality" Journal of Psychology in Africa, (2006), 16(2), $225-258$.

[6] Kirby, D. "School based programmes to reduce sexual risk-taking behaviours", Journal of School of Health, (1999), 62, $559-563$.

[7] Kirby, D. "Effective approaches to reducing adolescent unprotected sex, pregnancy and child bearing", American Journal of Research, (2002), 39(1), 51 - 57.

[8] Obiekea, P.O., Ovri, F.B. \& Chukwuma, E.T.C. "Sexual Education", An intervention and Social Adjustment Programme for Youths in Secondary Education in Nigeria. African Research Review 7 (1) s/No 28. (2013), 322-339.

[9] Okafor, P.N. \& Nnoli, I.M., 'Premarital sex and teenage pregnancy among adolescents and its counselling implications', The Lagos Counsellor, (2010), 3(1), 109 119.

[10] Oke, E. An appraisal of the prospects of teaching sex education in secondary schools in Ife South Local
Government. BSc(Ed) Dissertation, Obafemi Awolowo University, Ile-Ife, (2013).

[11] Olorunda, O.A., "Moral attitude of some Adolescent students in some secondary schools in Lagos: Implication for Counselling". M.Ed project submitted to University of Lagos, (1990).

[12] Oyinloye, O.A. 'Sexual education for reducing the prevalence of teenage pregnancy in Nigeria'. CICE- 2014 proceedings. (2014). 284-288.

[13]. Sandtrock J.W., Adolescence $10^{\text {th }}$ E McGraw Hill. Boston (2005)

[14] Resnick, M.D. \& Blum, R.W., Sexual intercourse during childhood with adolescents' health risk and behaviour. Paediatrics, (1994). 94 No 6 p. 207.

[15] Mellanby, A., Phelps, F., Tripps, J., "British Medical Journal", (1999), pp307-325. 